\title{
Growth of Fry Fish of 4 Species of Family Mugilidae in Experimental Recirculation Water System
}

\author{
George N. Hotos and Despina Avramidou
}

\section{ABSTRACT}

The collected in nature fry of Mugil cephalus, Liza aurata, L. ramada and Chelon labrosus that arrive in massive schools at the coastline of Greece were reared in small aquaria $(50 \mathrm{~L})$ of a recirculation system from the size of about $3.0 \mathrm{~cm}$ TL (50 fish per aquarium), using brackish (15 ppt) water and artificial high protein food. It was found that for a period of 80 days, growth performance was high at $23{ }^{\circ} \mathrm{C}$, reaching values for weight increase between 592 (M. cephalus) and $2281 \%$ (L. aurata). Food Conversion Ratio (FCR) was best (1.04) for L. aurata and worst (2.04) for M. cephalus. All species responded well as exhibited by an increase in their Condition Factor (CF) and mortality was almost absent.

Keywords: Mugilidae, recirculation, growth, Liza aurata, L. ramada, Mugil cephalus, Chelon labrosus.
Published Online: August 17, 2020

ISSN: 2684-5199

DOI : $10.24018 /$ ejbio.2020.1.4.46

\section{George N. Hotos *}

University of Patras, Greece. (e-mail: ghotos ${ }^{@}$ upatras.gr) Despina Avramidou University of Patras, Greece.

*Corresponding Author

\section{INTRODUCTION}

Growth of mugilid fish in various rearing facilities offers a promising future in terms of aquaculture expansion in Greece and elsewhere [1]. The first step in such procedures is the nursing of fry fish in as much as possible controlled conditions because the success of their initial growth will determine the wellbeing of the subsequent fattening. Mortality should be minimized and number of produced juvenile fish should be known in order to plan effectively their stocking program in the fattening ponds.

The mugilid fry fish (Total Length up to $3 \mathrm{~cm}$ ) can be easily collected in coastal waters [2] because they form dense schools with low escape ability from seine nets but on the other hand they are very delicate to be thrown directly to large rearing ponds as mortality will be uncontrolled [3] and the monitoring of their growth is impossible [4]. It is of paramount importance to treat the tiny fry properly at the initial stage of growing in controlled conditions and this can be done only in a recirculation aquaculture system (RAS). In such a system with appropriate warm water (above $20{ }^{\circ} \mathrm{C}$ ), low salinity (to the relief of osmotic burden) and ample food, mortality is minimized, and growth is expected to be maximized. At the end we come up with grown enough sturdy juvenile fish that can better endure the hazards of a tough environment such as that of a big earthen pond. This is particularly true in polyculture systems where mugilid species coexist with carps [5] and tilapias competing for space and food. Annually the coastal areas of Greece are flooded with new recruits of the 5 species of the Family of Mugilidae (Mugil cephalus, Chelon labrosus, Liza aurata, $L$. ramada and $L$. saliens) each of them having its own season of arrival that overlaps to a lesser or greater extent with others [2], [6]. They are especially abundant in estuaries and in the communication canals of the lagoons with the sea. It is important to collect them as early as possible, that is, massively when they are very small and unable to escape the net, otherwise in a later stage of development when they have grown enough $(>5-6 \mathrm{~cm}$ in T.L.) they are very effective net escapers and their schools are not massive.

The rearing of mugilid fry in a recirculation system has been scarcely studied [7], [8] and the present work aims to the presentation of data that will clarify the effectiveness of this operation. Excluding L. saliens that was known from previous trials to be very slow in growth, the study focused on the other 4 species that fetch a good price in the fish market [1].

\section{MATERIALS AND METHODS}

The experimentation took place in a air-conditioned laboratory using 3 autonomous recirculation water systems each of which consisted of 4 glass aquaria of $50 \mathrm{~L}$ volume each. Each system (of 4 aquaria) was served by a compact heavy-duty cartridge filter into which both mechanical and biological filtration continuously cleaned the water and returned it to the aquaria by proper pumping and piping. Each aquarium contained $40 \mathrm{~L}$ of water that was oxygenated by an air pump supply through perforated stones. The total water volume in each system $(4 \times 40 \mathrm{~L}=160 \mathrm{~L})$ was less of the maximum cleaning capacity of the filter, as the filter specifications allowed for serving up to $350 \mathrm{~L}$ of water. The water from the aquaria did not entered directly to the cartridge filter but instead it was first poured by gravity into a plastic vessel and then by a small pump was sent to the filter. This vessel served as a sump where settlement of debris, salinity adjustment, heating and sampling of water 
practiced. The water after its treatment in the filter was returned to the aquaria by its centrifugal pump and the flow was adjusted by vanes so as to achieve 2 volumes renewal per hour. All components were made entirely by plastic material.

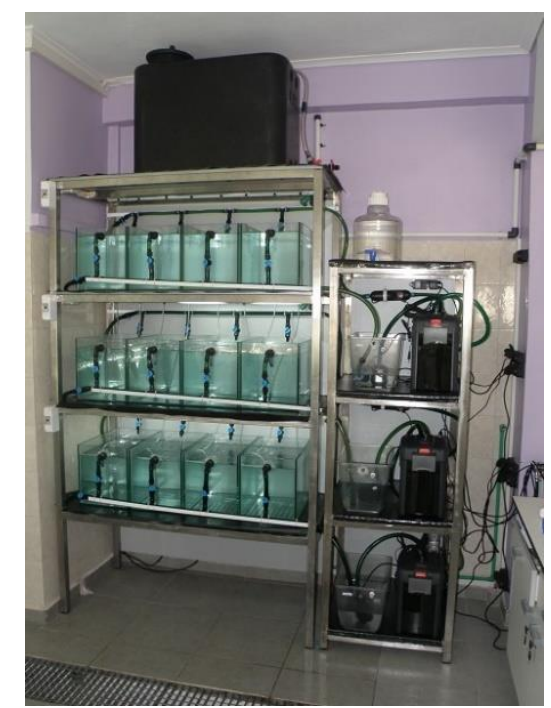

Fig. 1. The installation of the 3 recirculation systems used for the rearing of the mugilid fry. Each system is comprised of four 50 liters aquaria, a

gravity fed sump and a cartridge Eheim 350 complete filter. used vials for each feeding were recorded and the feed added for each meal known. At the end of the experimentation (80 days) the total food used was known and permitted for the estimation of Food Conversion Ratio (FCR).

The water temperature was kept at $23{ }^{\circ} \mathrm{C}$ by means of a thermostatically controlled aquarium heater immersed in the sump vessel. Salinity for all experiments was maintained at $15 \mathrm{ppt}$ because it was found from the literature [9] and our preliminary trials to be the most effective in keeping mortality low and the fry fish with high appetite. Illumination was the usual of the room following day and night rhythms, but during night hours a light was left on in the room avoiding complete darkness. Oxygen and $\mathrm{pH}$ were measured daily by electronic meter (WTW Multi 350i) and levels of total ammonia (TAN), nitrite and nitrate were monitored using aquarium test kits (Salifert-Holland). All dead fish were removed as soon as possible and any accumulation of debris on the bottom was siphoned out.

At the end of the rearing period ( 80 days) the whole mass of fish was collected anaesthetized and each of them was weighted and length-measured. After recovering, alive fish were freed to the adjacent lagoon. Data of growth, mortality, food consumption and physicochemical parameters were analyzed statistically by ANOVA using "PAST" software.

\section{RESUlts AND DisCUSSION}

Before the starting of the rearing experimentation, each operating system was conditioned in advance in order to establish an effective nitrifying bacterial population, aided by daily addition of small amounts of ammonium chloride (NH4Cl) so as to supply a stable amount of ammonia to multiplied nitrifying bacteria. The conditioning lasted in every case 30-40 days and only when readings (measured by test kits) of ammonia showed zero and nitrates peaked it was considered ready to introduce the fish and start the experimentation. The conditioning was carefully planned so as for the system to be ready to accept the stocking of fry that was collected from the coastal waters at the appropriate time for each species [1], [6]. Depending on the season of collection of each species from nature, the experimentation planned to use one system per species and no more than two systems simultaneously with overlapping periods of 80 days.

The collected fry was first acclimatized indoors in properly aerated vessels with water of 15 ppt salinity and remained there for 48 hours. Then the survived fish were anaesthetized by 2-phenoxyethanol $(0.3 \mathrm{ml} / \mathrm{L})$ and their weight $(\mathrm{g})$ and length $(\mathrm{cm})$ were recorded. Each of the 4 aquaria of each system in operation was stocked with 50 fish of the same species for the particular experiment. Feeding was accomplished with commercial small size $(0.2-1 \mathrm{~mm})$ crumbled food of $51 \%$ protein and $10 \%$ fat. The fish were fed twice a day by hand, adding food slowly till satiation was evident (proved by swollen bellies and stopping of feeding). During feeding the flow of the incoming water was stopped for avoiding any loss of food. In order to keep tracking of the food consumed and for avoiding its wasting a properly designed method was followed. That is the food was previously apportioned in small quantities of $0.5 \mathrm{~g}$ each contained in dozens of small glass vials. By this way the
In the experiments with the species L. aurata, L. ramada and $M$. cephalus collected in autumn-winter months (as their reproductive periods overlap [1], [6]), their initial mean sizes $(2.7 \mathrm{~cm}$ and $0.15 \mathrm{~g}$ for L. aurata, $2.10 \mathrm{~cm}$ and $0.07 \mathrm{~g}$ for L. ramada and $2.73 \mathrm{~cm}$ and $0.19 \mathrm{~g}$ for M. cephalus) were of the minimum amenable size (Table I) as they originated from the just arrived at the coasts cohorts. In experiment with fry of C. labrosus that was collected in late April, its size $(2.45 \mathrm{~cm}, 0.15 \mathrm{~g})$ was also similar to the previous species.

All species acclimatized well in the aquarium environment not showing any signs of stress. Their color remained silverish and their motility vivid. After the first 4 days they became fully used to the distribution of food concentrating massively at the front side of the aquarium not scared by humans. Food was consumed rapidly aided by careful distribution and this practice greatly facilitated the consumption calculations. During the period of 80 days of each species experimentation, due to previously fully conditioned biological filter the levels of the harmful unionized ammonia $\left(\mathrm{NH}_{3}\right)$ remained constantly very low $(<0.05 \mathrm{mg} / \mathrm{L})$ and any short peaks after meals quickly vanished. Dissolved oxygen never dropped below $7 \mathrm{mg} / \mathrm{L}$, $\mathrm{pH}$ fluctuated at 7.8-8.2, nitrites $\left(\mathrm{NO}_{2-}\right)$ were absent and nitrates $\left(\mathrm{NO}_{3}-\right)$ fluctuated at the region of $50-80 \mathrm{mg} / \mathrm{L}$. Because of the above values of parameters the rearing procedure was considered as absolutely safe for the fish not creating any bias that could jeopardize the growth features of the animals.

Mortality kept almost insignificant (Table I) and this is a positive situation as the data on mortality provided vaguely by older textbooks concerning the direct stocking of fry fish to earthen ponds present much higher values in the order of 
$50 \%$ [3], [10], [11].

L. aurata performed best in terms of increase in total length and weight followed by L. ramada and C. labrosus with $M$. cephalus far away. This rate of increase reflected in the specific growth rate (SGR) as L. aurata and L. ramada exhibited the highest SGR of length (1.31 and 1.30 respectively) followed by C. labrosus (1.2) with $M$. cephalus presenting far lowest value (0.75). Noticeable is the impressive increase of $L$. ramada whose initial size was much lower of all the rest (Fig. 2). The present data can serve as a guide for future similar experimentation as there are not found any relevant values in the literature concerning those sizes, nor there are any values concerning natural populations or data from extensive or semi-intensive culture of mugilids [3], [5], [10], [11].

TABLE I. THE GROWTH PARAMETERS FOR EACH SPECIES IN THE EXPERIMENTS.

SGR $=\left[\left(\operatorname{lnTL} L_{\text {final }}-\operatorname{lnT} L_{\text {initial }}\right) \times 100\right] / 80 . \mathbf{C F}=\left(\mathrm{W} / \mathrm{TL}^{3}\right) \times 100 . \mathbf{F C R}=$ Sum food/Final biomass.

\begin{tabular}{|c|c|c|c|c|}
\hline $\begin{array}{c}\text { Growth parameters } \\
(80 \text { days }) \\
\end{array}$ & Chelon labrosus & Mugil cephalus & Liza aurata & Liza ramada \\
\hline Number of fish stocked & 200 & 200 & 200 & 200 \\
\hline TL (cm) (initial) $( \pm \mathrm{sd})$ & $2.45^{\mathrm{a}}(0.28)$ & $2.73^{\mathrm{b}}(0.19)$ & $2.72^{\mathrm{b}}(0.24)$ & $2.11^{\mathrm{c}}(0.12)$ \\
\hline $\mathrm{W}(\mathrm{g})$ (initial) $( \pm \mathrm{sd})$ & $0.15^{\mathrm{a}}(0.05)$ & $0.19^{\mathrm{b}}(0.04)$ & $0.15^{\mathrm{a}}(0.04)$ & $0.07^{\mathrm{c}}(0.01)$ \\
\hline $\mathrm{W}(\mathrm{g})($ final $)( \pm \mathrm{sd})$ & $2.92^{\mathrm{a}}(1.21)$ & $1.31^{\mathrm{b}}(0.49)$ & $4.00^{\mathrm{c}}(0.80)$ & $1.91^{\mathrm{d}}(0.97)$ \\
\hline Mortality (N) & 8 & 3 & 3 & 2 \\
\hline Initial biomass (g) & 34 & 42 & 32 & 21 \\
\hline Final biomass (g) & 580.5 & 290.6 & 762 & 393 \\
\hline SGR (\%/d increase of TL) & 1.20 & 0.75 & 1.31 & 1.30 \\
\hline$\%$ increase biomass & 1607 & 592 & 2281 & 1770 \\
\hline Initial CF ( \pm sd) & $0.97(0.10)$ & $0.93(0.10)$ & $0.78(0.10)$ & $0.77(0.06)$ \\
\hline
\end{tabular}

Superscripts $(a, b, c, d)$ denote statistically equality or difference by Tukey's pair-wise comparisons at the 0.05 level of significance between species concerning TL and W and signs (+, -) represent t-test $(0.05$ level) comparisons between CFs of the same species from the end of experimental period and similar sized fish from nature. All values are means.
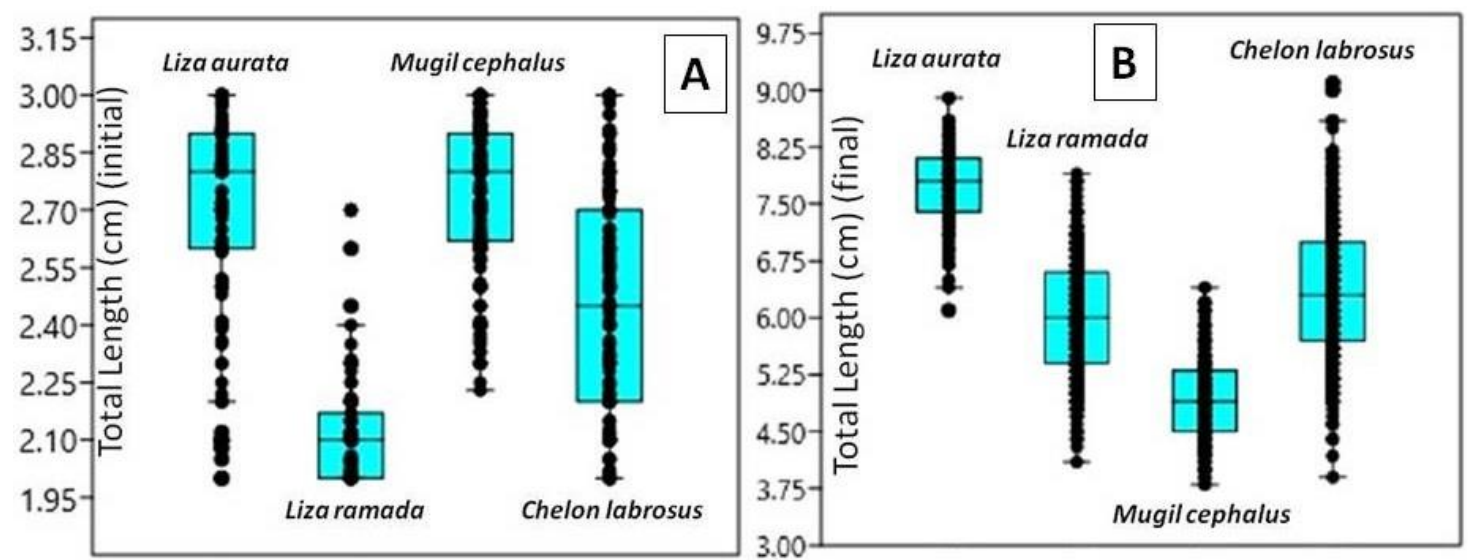

Fig. 2. Box-plot depictions of body lengths (as Total Length) of the 4 species at start (A) and at the end of the experimentation (B).

Food Conversion Ratio (FCR) exceeded the value of "2" only in the case of $M$. cephalus, in all other species kept below 1.5 with $L$. aurata and $C$. labrosus exhibiting incredibly low values ( $1.04 \& 1.09$ respectively) a clue for their potential of advantageous growth in intensive rearing systems as it indicates that they can do the best with highly proteinaceous artificial food [12], [13], [14]. To what extend this also applies to other cheaper and lower $(<50 \%)$ in protein food, should be tested in future experiments.

Comparing growth of small mugilids between fish in nature and those reared in captivity is another difficult task as data are inconsisted by default because you cannot compare free populations with populations in captivity. A clue only can be given comparing the condition factor of similar sizes, that is, those originated from naturally captive fish and those from the rearing system. Fortunately for the present study such data exist for these species [1] and in Figure 3 they are depicted for 3 species because for $L$. ramada there were not available nature captured similar sizes.

The condition factor (CF) is index of robustness and as expected, C. labrosus and M. cephalus the most bulkiest of all in nature exhibited the highest values of 1.07 and 1.03 respectively. Remarkably the CF of all species at the end of the rearing period improved greatly from the initial ones $(\mathrm{t}-$ test, $\mathrm{p}<0.05)$, a clear sign of an excellent growth in recirculation system (Table I). The CF attained at the end of the rearing period was tested against the $\mathrm{CF}$ for relevant sizes from naturally collected samples and it was found bigger in C. labrosus (1.07 vs 0.97$)$ and M. cephalus $(1.03$ vs 0.98 ) and equal to L. aurata (0.86 vs 0.87 ) (Table I and Fig. 3). This fact indicates that the condition of fish at this developmental stage is not affected negatively from the artificial environment of rearing, on the contrary for some of them can be beneficial boosting their growth. Fish with high $\mathrm{CF}$ can be better bodied equipped to confront the harsh 
environment of open ponds when they will be introduced there for fattening.
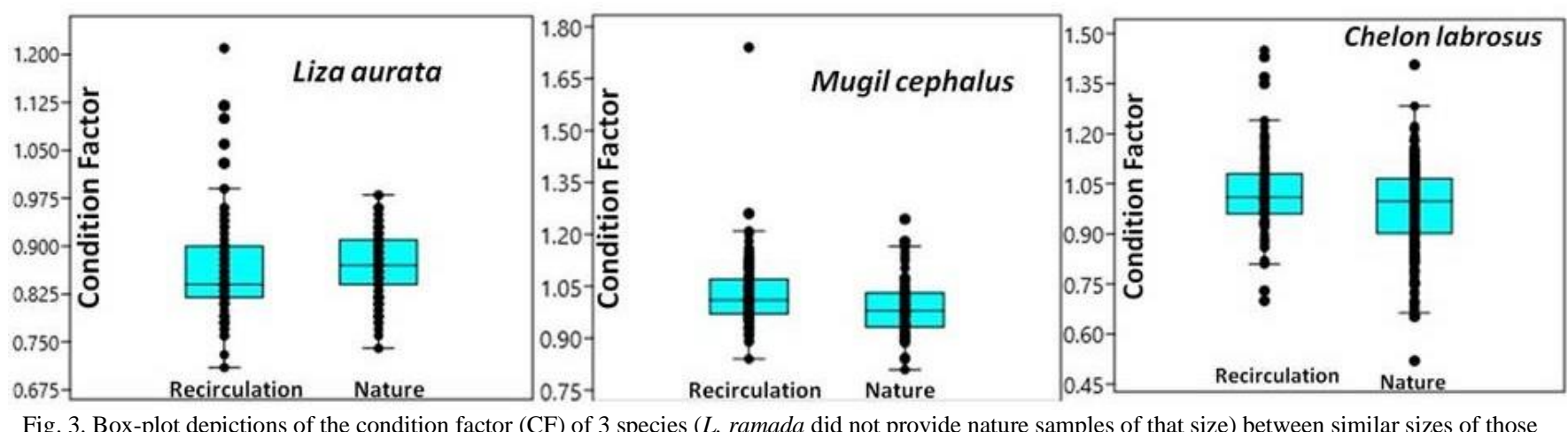

Fig. 3. Box-plot depictions of the condition factor (CF) of 3 species (L. ramada did not provide nature samples of that size) between similar sizes of those attained in the recirculation experiment after 80 days and those from nature captured fish.

All data presented here concerning the initial growth of mugilid fry fish from the minimum size that can be collected in the field $(2-3 \mathrm{~cm}$ TL) till a quite juvenile size $(\sim 5-7 \mathrm{~cm}$ TL) should be considered as the basis for future similar experimentations because the literature lacks data for this developmental stage. All other works on intensive rearing (quite limited) of mugilid fry fish and especially in recirculation systems start with bigger fish $(\sim 6 \mathrm{~cm}$ TL) [7], not including all species [12], [14], [15], or in cases concerning just stocking of ponds with the newly collected fry (2-3 cm TL) or do not provide any detailed growth data [4], [5], [10].

Based on the findings of the present study more detailed works should be done on rearing those 4 species for more than 80 days, using fresh and salt water, several kinds of food, fish densities etc in order to clarify to the full extend the parameters of their growth in captivity. Overall purpose should be the standardization of the procedure that results in least mortality, maximum growth and low cost food of maximum conversion ratio.

\section{CONCLUSION}

The experimentation revealed that mugilid fry fish collected from coastal waters can readily grow in a recirculation rearing system and take artificial food with no mortalities if the physicochemical features of the water remain in safe levels. The growth of fish of all 4 species used was impressive with more than doubling their initial weight in 80 days. L. aurata presented the most impressive increase of weight $(2281 \%)$ and $M$. cephalus the lowest (290,6\% although satisfactory). Comparing the Condition Factor of fish at the end of the experimentation with that of wild caught fish of the same size revealed that the reared fish were not handicapped because of confinement. It is beneficial for the rearing of mugilid fish in earthen ponds to initially raise them in a intensive system so as to become sturdy to better overcome the hazards of the big earthen ponds and be grown enough to facilitate more efficient feeding.

\section{ACKNOWLEDGMENT}

The authors would like to express their thanks to the head of the former Technological Educational Institute (T.E.I.) of Western Greece (now incorporated to the University of Patras, Greece) for providing any kind of help for the materials needed for the experiment.

\section{FUNDING}

This research was not financially supported by any type of funding.

\section{ETHICS APPROVAL AND CONSENT TO PARTICIPATE}

The study was conducted in accordance with institutional and national guidelines for handling the experimental.

\section{REFERENCES}

[1] Hotos, N. G. and Katselis, N. G., 2011. Age and growth of the golden grey mullet Liza aurata (Actinopterygii: Mugiliformes: Mugilidae), in the Messolonghi-Etoliko lagoon and the adjacent gulf of Patraikos, Western Greece. Acta Ichthyologica et Piscatoria, vol. 41(3), pp. 147157.

[2] Hotos, N. G., 1999. Biology and population dynamics of the golden grey mullet Liza aurata (Risso, 1810) (Pisces: Mugilidae) in the lagoon of Messolonghi-Etoliko. PhD thesis. University of Patras, Greece, 415 p. (In Greek with English summary).

[3] Liao, C.I., 1981. Cultivation methods. In: Oren, H.O. Aquaculture of grey mullets. Cambridge Univ. Press, pp. 361-389.

[4] Ben-Yami, M., 1981. Handling, transportation and stocking of fry. In: Aquaculture of grey mullets (ed. by O.H. Oren). Cambridge Univ. Press, p. 335-352.

[5] Hepher, B. \& Pruginin, Y., 1981. Commercial Fish Farming. With special reference to fish culture in Israel. John Wiley \& Sons. 261p.

[6] Katselis, G., Minos, G., Marmagas, A., Hotos, G. and Ondrias, I., 1994. Seasonal distribution of Mugilidae fry and juveniles in Messolonghi coastal waters, Western Greece. Bios (Macedonia, Greece), vol. 2, pp. 101-108.

[7] Nita, N. V., Nenciu, M-I. and Nicolae, G. C., 2018. Experimental rearing of the golden gray mullet Liza aurata (Risso, 1810) in a recirculating system at the Black Sea. Sciendo. pp. 149-154. DOI:10.2478/alife-2018-0022.

[8] Hotos, G. and Vlahos, N., 2000. Preliminary study of the growth of 4 mugilid fry in closed system. $6^{\text {th }}$ Panhellenic Symposium of Oceanography and Fisheries, 23-26 May, Hios island Greece. vol. 2, pp. 358-360, (in Greek with English summary).

[9] De Silva, S. S. and Perera, A. B. P., 1976. Studies on the young grey mullet, Mugil cephalus L. Effects of salinity on food intake, growth and food conversion. Aquaculture, vol. 7, pp. 327-338.

[10] Korringa, P., 1990. "Valliculture": Mullet Farming on the Adriatic coast of Northern Italy. In: P. Corringa (ed) Farming marine fishes and shrimps. Elsevier, 208 p. 
[11] Sarig, S., 1981. The Mugilidae in polyculture in fresh and brackish water fishponds. In: Oren, H.O. (ed) Aquaculture of grey mullets. Cambridge Univ. Press. pp. 391-409.

[12] Honer, G., Hillers, A., Konjevic, D. and Milosevic, S., 1989. Growth of mullet (Liza ramada) fed three commercial trout and eel feeds in open and closed aquaculture systems. J. Appl. Ichthyol., vol. 5, pp. 157-164.

[13] Papaparaskeva-Papoutsoglou, E. and Alexis, N. M., 1986. Protein requirements of young grey mullet, Mugil capito. Aquaculture, vol. 52, pp. 105-115.

[14] Vallet, F., Berhaut, J., Leray, C., Bonnet, B. and Pic, P., 1970 Preliminary experiments on the artificial feeding of Mugilidae. Helgolander wiss. Meeresunters, vol. 20, pp. 610-619.

[15] Chervinski, J., 1975. Experimental raising of golden grey mullet [ Liza aurata (Risso)] in saltwater ponds. Aquaculture, vol. 5, pp. 91-98.

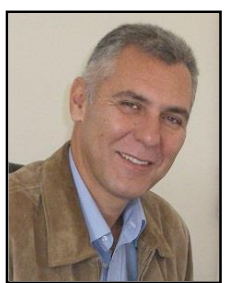

George N. Hotos is a professor of Aquaculture an Phycology in the Department of Animal Production, Fisheries and Aquaculture, University of Patras, Greece. He got his bachelor degree of biology from the university of Patras (1980), his master degree in Ichthyology from Mie University, Japan (1984) and his doctorate in biology of mugilid fish from the university of Patras (1999). His professional academic career spans more than 35 years engaging in all fields of applied ichthyology such as field studies, raising fish in recirculation systems, aquarium keeping, histology of fish tissues, algae culture, zooplankton culture, etc. He has created in his department an aquaculture laboratory and a plankton culture laboratory. Apart from publications he is committed to internet publishing analytical essays in basic fields of aquatic life and various videos in his YouTube channel. 